\title{
RESOCIALIZING PROGRAMS OF THE PERPETRATORS OF PARTICULARLY VICIOUS MURDERS
}

\author{
Waldemar Woźniak \\ Section of Forensic and Penitentiary Psychology Institute of Psychology Cardinal Stefan Wyszyński \\ University, Warsaw, Poland
}

Key words: resocialization, prison, penitentiary system, prisoners' crises, murderers, particular viciousness, social work, social resocialization.

\begin{abstract}
Summary
Resocialization is a complex and difficult process if only due to its targeting individuals in specifically critical situations that is those imprisoned, gravely demoralized socially, which shows in case of the perpetrators of particularly vicious murders. They can use their brutal act to dominate in the given prison group. During their imprisonment, they seem immune to the classical resocialization paradigm. Thus, the resocialization process should have new elements introduced, such as consultancy, various forms of help and volunteering. Such activities can be labeled as 'social resocialization', to use the term authored by Professor P. Stępniak.
\end{abstract}

\section{Introduction}

Social security is of inconvertible value, crucial in furthering both general social progress and that of every individual. By nature, criminal offence is individual but considered globally it influences sense of security in a variety of ways. Due to the complex nature of the origins of offence, resocializing procedures must be flexible to be more and more effective. They must consider various categories of perpetrators, together with related psychosocial processes. The author sets out to discuss a specific group of particularly vicious murderers.

My research presented in the present paper shows that those perpetrators may show disordered personality structure (such as impulsiveness, irascibility).

\section{Resocialization as a problematic concept}

In Poland, the term resocialization is easy to discern, not so much in Western Europe, where one can find a mo- del of penitentiary social work. The exact meaning of the term concerns the individuals in prison and juvenile detention centers. In case of prisoners and adolescent offenders we can talk about delinquency (breaking legal norms), which means the highest degree in the process of social disadaptation.

Prisons and juvenile detention centers are administered by The Ministry of Justice, which is responsible for resocializing practices there. Broadly speaking, resocializing concerns young people living in society but threatened with social pathology. In open environment, it is more suitable to identify 'resocialization' with various forms of social prevention. In case of broad but exact understanding of the term, resocialization may comprise all dissocial individuals, whose socialization processes have been disrupted due to various factors. However, this is not a legitimately employed notion, for it seems that a majority of people revealing various levels of socializing disorders commit no crimes. All in all, it makes the term 'resocialization' truly problematic. A. Fidelus writes:

Resocialization will be effective if socializing values won't contradict resocializing guidelines. Resocialization process takes place in the context of socializing process. Socially disadapted individuals undergo both processes. Dividing these processes is possible only in theory. Even if an individual is imprisoned and seems to be exposed directly to the process of resocialization, he is also influenced by socialization (the media, contacts with other individuals from outside prison). The condition of proper social adaptation of an individual is a mutual, complementary activity within both processes, in transferring contents, norms and rules $[4,31]$.

G. Marshall's Oxford dictionary of sociology and social sciences defines resocialization as:

The relearning of cultural norms and sanctions, on their return to a social system, by those who voluntarily or involuntarily left that system (such as prisoners re-entering 
society or expatriates returning from abroad) so that they can again be fully accepted within that system $[14,279]$.

I find the above definition too broad and questionable because of coupling perpetrators and migrants, as the latter may not concern delinquency of the former. Frequently, I also come across somewhat unintelligible use of the term.

L. Pytka [18, 73-77] presents various meaning of 'resocialization' concerning delinquents: resocializing means modifying behaviour, changing 'social affiliation', emotional rebuilding, settling into culture, satisfying needs, shaping correct social attitudes, character shaping, a kind of 'conversion' to higher values, reconstructing personal identity [cf. 10].

Contemporary penitentiary system with resocializing procedures, as its basic element, is rooted in the first cell system, the so called Ghent system established in 1775 . The Ghent system introduced the principle of daily work in common rooms with an order to stay silent and nighttime in single cells. The system became a model for American system called the Auburn System in 1816. There prison inner cells had neither doors nor windows only bars separating them from the corridor, which was criticized for reminding of wild animal cages. In the Pennsylvanian system (in 1790) the principle of complete round the clock isolation was accepted simultaneously with total inactivity of the prisoners, to be changed to for solitary work and resignation from absolute isolation [3, 185-187]. In the above instances of the cell system, isolation (keeping silent) and work became basic resocializing measures.

Two systems of detention operate in Poland today, besides an ordinary one there is also a system of programmed and therapeutic procedures [9, art. 81]. The system of programmed activities allows for individual treatment of the problems of a given perpetrator, such as his contacts with the family or fulfilling his duties, to prepare for his return to society. The therapeutic system can help in preventing pathological personality traits (for instance in alcohol abusers) and in regaining psychic harmony [9, art. 95, 97].

Introducing individual or therapeutic approach means abandoning classical attitudes in which the problems of punishment and isolation come to the foreground. More so that individual attitude cannot be separated from the counseling paradigm.

The above remarks show broadening and evolution of the means of resocialization and re-adaptation - from isolation, via work to counseling and therapy.

The problem of crisis in the context of resocialization

'Crisis' is not an easy cognitive problem considering its sources, forms and progress. Crisis is a polymorphous phenomenon of characteristic dynamism and time span.
One may speak about psychological crisis, physiological or moral. Then, crisis would stand for a prolonged sate of disharmony.

In case of prisoners, one can speak about yet another - existential crisis, besides the three already mentioned. It happens as the detainee meets with strict principles of informal functioning, which he fails to understand, which he accepts 'intuitively' to get used to prison isolation and live though it in the state as little disturbed as possible. All these keep him anxious and insecure. Prisoners experience some existential fears afraid of degradation in the community of fellow prisoners, which may combine with becoming a victim of aggression, bullying and persistent violence. Individuals may accept prison anti-values to keep a relatively high position in the informal hierarchy invented by prisoners themselves, which ultimately leads to axiological crisis and diminishes resocialization effectiveness.

Z. Płużek enumerates the following personality crises: organic, endangering inner integrity, causing huge changes in living environment, interpersonal, socio-cultural, originating from lack of information, developmental, suicidal, weakened coping abilities in difficult situations and religious crises [17, 97-126].

The crises detainees experience are polymorphous, piling up on one another leading to a major crisis difficult to diagnose and counteract. Such crisis brings stress and internal conflicts.

\section{Perpetrators as a diverse group}

There are several kinds of homicides, thus several types of perpetrators. Describing the origins of violence, A. Bałandynowicz [1, 44-46] lists Old Testament murders as committed treacherously, in revenge of the perpetrator on the victim, wartime murders and related ones, murders committed as a punishment for real or alleged offences (inflicted by the representatives of a given community).

Considering the value system, homicides may be divided into egodystonic (committed contrary to the perpetrator's conduct so far) and egosyntonic (in agreement with the perpetrator's life style so far) [13, 66-67].

J. Malec classifies killers according to their aims: committed in rage (infuriated perpetrators do not think about the consequences of the assault), crimes of passion, robbery killing, to bump off an inconvenient person, as revenge for damages experienced, erotic (jealousy) homicide and sexual motivated homicide to satisfy sex drive [13, 71-98].

Polish Penal Code lists three types of homicide, basic ('ordinary') and classified ('tough') including particularly vicious ones and 'privileged' ones (i.e. crimes of passion) [8, art. 148]. There are types of killers, such as terrorist killers, contract killers, mass killers (killing in undetermined anger, 
many victims in a single act of extreme violence), serial killers, where pleasure seems a basic motive [22, 129-131].

I am going to refer to significant research results of two recognized Polish scholars, Professor J. K. Gierowski and Professor Z. Majchrzyk. Gierowski's [6] research included 105 persons (16 females and 89 males). Employing cluster analysis six groups of perpetrators were singled out according to the leading motive. These motives were: economic (22); sexual (16); delusive (13); vindictive (17); grievance (13); fear and menace, jealousy, based on negative emotions (24).

Z. Majchrzyk researched 200 males, 110 adult, 27 adolescent (from 15 to 17), and 63 juvenile (under 21). Five clusters that were singled out contained leading motives and accompanying ones (here only the former are given). Cluster A robbery $(\mathrm{N}=57)$; cluster $\mathrm{B}$ revenge $(\mathrm{N}=60)$; cluster $\mathrm{C}$ sexual motives $(\mathrm{N}=33)$; cluster $\mathrm{D}$ emotive aggression $(\mathrm{N}=26)$; cluster $\mathrm{E}$ fear/resentment $(\mathrm{N}=24)$. Adolescent and juvenile offenders dominated in clusters $\mathrm{A}$ and $\mathrm{D}$, adults in others [12].

Besides social conditioning, personal dispositions of the offenders and criminal motives determine their behaviour, alongside with value systems, in particular those of marginalized groups and individuals. One must realize that important shifts took place in the adolescent value system, in which human life went down the scale. The taking of somebody's life has ceased to be a taboo, in spite of severe punishment. Besides personality disorders, there are other sources of inexplicable and extreme offences, such as unemployment, lack of perspectives (especially among the socially excluded), widening areas of poverty and a conviction that offence (murder) is a means of easy life [12, 346-347].

Killers' diversity makes it difficult to conduct proper resocializing and therapeutic procedures. Investigating complex problems of the perpetrators must dwell upon the social consequences of their deeds.

The author's research concerning the perpetrators of particularly vicious homicide

Hideous behaviour of the perpetrator, inflicting severe pain physical and moral qualify as properties of utmost cruelty. Employing the term of utmost cruelty involves evaluating which cruelty is 'ordinary' and which is 'exceptional'. We refer to exceptional cruelty when it exceeds average measure $[2,286]$. In Polish Penal Code manslaughter with exceptional cruelty has been singled out in art.148 § 2 p. 1 .

In 2009 I conducted a five stage investigation on the perpetrators of particularly vicious homicides [21]. In stage one the case of one particularly vicious murder, committed in 1994, was analyzed. The perpetrator made a written statement allowing me to use his full name, which however I refrain from doing here, as my aim is to concentrate merely on the gist of the problem. Serving his prison term, the person seemed immune to penitentiary and resocializing procedures until given considerable support from several people, which made him believe that returning to society was possible.

In stage two, I analyzed ten written testimonials from penitentiary psychologists concerning the personality traits characteristic for those who murdered with utmost cruelty. Among others, the testimonials indicated that the offenders had little ability to postpone gratification and revealed disturbed sentiments. When frustrated, they often acted impulsively, angrily, and became aggressive when contradicted. In majority they felt they must be in charge and need to dominate others. Sentenced for particularly cruel crimes, they showed lower ability to experience guilt.

In stage three I analyzed criminal files of 34 men, mainly young, convicted for particularly vicious murders, serving in one prison in Poland. Thirty of them were first time offenders and homicide was the first offence (88.24\%). Thirty one of them were single (91.18\%). Slight mental impairment was diagnosed in 6 cases $(17.65 \%)$, which still made them accountable. Personality disorder was diagnosed in 23 cases $(67.65 \%)$.

In stage four the experimental group of 30 , out of 34 , perpetrators of particularly vicious murders was tested, those whose files had been analyzed previously. The tests included Personality Inventory NEO-FFI and Questionnaire of Emotional Intelligence INTE. The control group consisted of 30 prisoners convicted for ordinary theft. Two statistically significant differences showed. The experimental group showed increased neuroticism and decreased ability for compromise when compared with the control group. The result was unfavorable for murderers with particular cruelty. Their 'ability for compromise' was down to 4 sten, which is rather low.

The last stage consisted of analyzing 20 written statements of prison tutors, completed at my request, concerning the greatest difficulties in the process of social readaptation of vicious killers. The group was considered claiming and arrogant, even ruthless, partaking in scuffles and strongly identifying with prison sub-culture ("the other life'). They may use their crimes to secure high positions in the group. They seemed immune to 'normal' resocializing procedures and often presented themselves as 'victims' of the society.

\section{Looking for an effective model of resocialization}

So far, the findings concerning extremely vicious perpetrators indicate that their psycho-social image and persona- 
lity structure must be considered unfavorable. Committing such a vicious crime also associates with stigmatization. Then, several defense mechanisms are initiated. I am sure that in spite of repression mechanism (an attempt to shed the responsibility on others or society), the perpetrators are aware of them and living with such awareness becomes the most severe punishment.

The above reasons make it possible for the discussed group of offenders to shut themselves from resocializing procedures offered in the Polish penitentiary system today. My personal resocializing contacts and ensuing 'participating observations' indicate that they are able to accept some support (in the broad sense of the word), which they will not consider as coming from the prison corrective system.

\section{K. Ostrowska writes:}

Social support is a process during which an individual or a group facilitate fulfilling psychic, social and spiritual needs for another individual or group, help solve inner and outer conflicts, accompany them in overcoming troubles, difficulties, frustrations and daily stresses [16, 85].

Such understanding of social support can be included in the model of resocializing measures directing toward such principles of social work as charity, social justice, help, complementarity, interventionism - life saving, emergency assistance $[7,77-78 ; 15,35-38]$. Social work aims at supporting individuals and families in regaining full participation in social life, reinforcing local communities in independently resolving their problems, organizing various forms of help and creating appropriate social policy [15, 30]. Analyzing the above goals, one can see that resocialization refers to the period of imprisonment, while social work has broader scope of help, which should be also given after release.

Prisoners accept social support more readily than correction or legal procedures that they often consider imposed, which, in turn, makes them less effective. In practice, resocialization in Poland seems directed only at the prisoner. Encompassing the individual, more importantly, social work also includes social policy, both local and national.

Poland has not developed juristic social work, such as France or Britain have. Due to this fact, professor Stępniak advocates a common sense approach to prisoners, the one that links the traditional with the modern, calling it 'social resocialization' $[19,97]$. According to me, the model of 'social resocialization' would mean introducing as many elements of social work into the current Polish resocialization system, such as social support, consultancy, and volunteering, which in my experience are well received by the perpetrators of particularly vicious murders. Of course, one must realize that introducing programmed and therapeutic procedures would mean abandoning the classical model based on isolation and work.

\section{Conclusion}

Exceptionally vicious killers show a disadvantageous psychosocial picture, thus resocializing process must include several elements from the range of social work, such as consultancy and genuine willingness to help, which may make them less adverse to resocializing procedures, but create better chance for their effective return to society. Such procedures can be called 'social resocialization', which may compensate for the absence of a paradigm of juristic social work in Poland.

The model of 'social resocialization' seems more helpful than traditional psycho-correction, to initiate a general biophilial tendency, first perhaps as mere impulse, then pro life attitudes [20, 187-192]. E. Fromm defines biophilia as ardent love toward and all living creatures, desire for progress of people and plants, ideas or social groups $[5,408]$. In turn, such tendencies should broaden inner freedom of each prisoner, the freedom on which his return to society and proper social functioning may rest [cf. $11,81-95]$.

\section{References}

1. Bałandynowicz A. Prageneza przemocy. In: Hołyst B. (ed.). Przemoc w życiu codziennym. Warszawa, 1997: 38-50.

2. Bojarski T, Michalska-Warias A, Piórkowska-Flieger J, Szwarczyk M. Kodeks karny. Komentarz. Warszawa, 2009.

3. Ciosek M. Psychologia sądowa i penitencjarna. Warszawa, 2001.

4. Fidelus A. Determinanty readaptacji społecznej skazanych. Warszawa, 2012.

5. Fromm E. Anatomia ludzkiej destrukcyjności. Poznań, 1999.

6. Gierowski JK. Motywacja zabójstw. Kraków, 1989.

7. Kawula S. Pomocniczość i wsparcie. Olsztyn, 2002.

8. Kodeks karny. Ustawa z dnia 6 czerwca 1997 r. In: Kodeks karny. Kodeks postępowania karnego. Kodeks karny wykonawczy. Kodeks wykroczeń. Kodeks postępowania w sprawach o wykroczenia. Kodeks karny skarbowy. Ustawa o opłatach w sprawach karnych. Ustawa o postępowaniu w sprawach nieletnich. Warszawa - Oficyna a Wolters Kluwer business, 2009: 17-196.

9. Kodeks karny wykonawczy. Ustawa z dnia 6 czerwca 1997 r. In: Kodeks ... (jw.). Warszawa - Oficyna a Wolters Kluwer business, 2009: 479-614.

10. Lipiński S. Metodyka wychowania resocjalizującego w placówkach zamkniętych. Łódź, 2009.

11. Lipiński S. Ontologiczne i psychospołeczne aspekty wolności człowieka. Pedagogia Christiana. 2004; 14 (2): 81-95.

12. Majchrzyk Z. Nieletni, młodociani i dorośli sprawcy zabójstw. 
Analiza procesów motywacyjnych i dyspozycji osobowościowych. Warszawa, 2001.

13. Malec J. Zabójstwa i związane z nimi problemy wiktymologiczne. Raport z badań. Warszawa, 2003 (komputeropis).

14. Marshall G. (ed.). Słownik socjologii i nauk społecznych. Warszawa, 2008.

For the def. in English: GORDON MARSHALL. "resocialization." A Dictionary of Sociology. 1998. Encyclopedia.com. 2 Sep. $2015<$ http://www.encyclopedia.com>.

15. Olubiński A. Praca socjalna. Aspekty humanistyczne i pedagogiczne. Toruń, 2004.

16. Ostrowska K. Psychologia resocjalizacyjna. W kierunku nowej specjalności psychologii. Warszawa, 2008.

17. Płużek Z. Psychologia pastoralna. Kraków, 1991.

18. Pytka L. Różne ujęcia resocjalizacji. In: Urban B, Stanik JM. (eds.). Resocjalizacja. Teoria i praktyka pedagogiczna. T. 1. Warszawa, 2007: 73-77.

19. Stępniak P. Praca socjalna czy socjalna resocjalizacja. W poszukiwaniu nowego modelu. In: Szecówka A, Koukola B, Kwiatkowski P. (eds.). Teoria i praktyka resocjalizacyjna wobec współczesnych zachowań dewiacyjnych w Polsce i Republice Czeskiej. Wrocław, 2008: 89-98.

20. Woźniak W. Biofilityczne ukierunkowanie resocjalizacji sprawców zabójstw. In: Pastwa-Wojciechowska B. (ed.). Człowiek w obliczu prawa. Kraków, 2008: 187-192.

21. Woźniak W. Readaptacja społeczna sprawców zabójstw ze szczególnym okrucieństwem. Ružomberok, 2013 (habilitačná práca H 013380, komputeropis).
22. Woźniak W. Tipologia degli autori degli omicidi. In: Kardis K, Kardis M. (eds.). Zborník religionistických a sociologických štúdií. Prešov, 2011: 123-136.

\section{RESOCIALIZACIJOS PROGRAMOS, SKIRTOS NUTEISTIESIEMS, PADARIUSIEMS YPAČ ŽIAURIAS ŽMOGŽUDYSTES \\ W. Woźniak}

Raktažodžiai: resocializacija, kalèjimas, penitenciarinė sistema, kalinčių asmenų krizès, socialinis darbas.

Santrauka

Resocializacija yra sudètingas, sunkus procesas vien dèl to, kad taikomas asmenims, kurie yra specifinèje, krizinèje situacijoje ir penitenciariai izoliuoti. Atlikti tyrimai parodè, kad itin žiauriu žmogžudysčių vykdytojams būdingi tokie asmenybės ypatumai, kaip impulsyvumas, piktumas. Savo nusikaltimo pobūdị jie gali panaudoti, norédami dominuoti kalejjimo grupèje. Atliekant laisvès atėmimo bausmę, šie kaliniai yra atsparūs resocializacijos klasikinėms paradigmoms, todèl i jų resocializacijos procesą reikia ịtraukti kitokius socialinio darbo modelių elementus: patarimus, įvairiapusišką pagalbą, savanorystę.

Adresas susirašinėti: z.majchrzyk@neostrada.pl

Gauta 2015-12-11 